\title{
Interleukin-10 Reduces Neurogenic Inflammation and Pain Behavior in a Mouse Model of Type 2 Diabetes
}

This article was published in the following Dove Press journal: Journal of Pain Research

\author{
Brandon M Yanik' \\ Jacqueline R Dauch (D) \\ Hsinlin T Cheng $\mathbb{D}^{1,2}$ \\ 'Department of Neurology, University of \\ Michigan Medical Center, Ann Arbor. \\ Michigan, USA; ${ }^{2}$ Department of \\ Neurology, Massachusetts General \\ Hospital, Harvard Medical School, \\ Boston, Massachusetts, USA
}

Purpose: Neurogenic inflammation is a major component of chronic neuropathic pain. Previously, we established the $\mathrm{db} / \mathrm{db}$ mouse as an animal model of painful diabetic neuropathy (PDN) of type 2 diabetes. In the current study, we investigate the roles of interleukin (IL)-10, an anti-inflammatory cytokine, in the development of neurogenic inflammation and pain behavior in $\mathrm{db} / \mathrm{db}$ mouse.

Materials and Methods: We first studied IL-10 expression in lumbar dorsal root ganglion (LDRG) neurons of $\mathrm{db} / \mathrm{db}$ mice using immunohistochemistry, immunoblots, and reverse transcription polymerase chain reaction during the period of pain behavior (from 8 to 16 wk of age). To determine if the reduced IL-10 expression mediates the mechanical allodynia in $\mathrm{db} / \mathrm{db}$ mice, we administered recombinant mouse IL-10 or saline (control) intraperitoneally to control $\mathrm{db} /+$ and $\mathrm{db} / \mathrm{db}$ mice starting at $8 \mathrm{wk}$ of age. IL-10 treatment was repeated every other day for $2 \mathrm{wk}$ until the mice reached $10 \mathrm{wk}$ of age.

Results: During the period of pain behavior, reduction of IL-10 protein and gene expression was detected in LDRG of $\mathrm{db} / \mathrm{db}$ mice. Treatment with recombinant IL-10, from 8 to $10 \mathrm{wk}$ of age, alleviates pain behaviors in $\mathrm{db} / \mathrm{db}$ mice without affecting other diabetic parameters. In parallel, IL-10 treatment reduced the upregulation of nerve growth factor (NGF), inducible nitric oxide synthase (iNOS), tumor necrosis factor (TNF)- $\alpha$, and high-affinity NGF receptor (Trk A) in LDRG, as well as the numbers of iNOS-positive Langerhans cells and CD-68positive dermal dendritic cells in the hind-foot-pad skin in $\mathrm{db} / \mathrm{db}$ mice.

Conclusion: Our findings suggest that the reduction in neuronal IL-10 increases inflammatory phenomena, ultimately contributing to PDN. These results suggest that the dysregulation of cytokine-mediated inflammation contributes to the development of PDN in $\mathrm{db} / \mathrm{db}$ mice. Targeting this pathophysiologic mechanism could be an effective approach for treating PDN in type 2 diabetes.

Keywords: dorsal root ganglion, painful diabetic neuropathy, cytokine, Langerhans cells, type 2 diabetes

\section{Introduction}

The prevalence of type 2 diabetes has been rapidly increasing around the globe. In the United States, the diabetic population has tripled in the last 30 years and reached greater than 30 million (www.CDC.gov). Diabetic neuropathy is a common complication that affects greater than $50 \%$ of patients with type 1 or type 2 diabetes. ${ }^{1}$ Most of the patients with diabetes develop length-dependent polyneuropathy that frequently presents as painful diabetic neuropathy (PDN) that includes symptoms of spontaneous burning, tingling pain, hyperalgesia
Correspondence: Hsinlin T Cheng Massachusetts General Hospital, Harvard Medical School, WACC 835, 55 Fruit Street, Boston, MA 02II4, USA

Tel +1 2 617-724-6213

Fax + 2 617-724-0895

Email htcheng@mgh.harvard.edu
Journal of Pain Research 2020:13 3499-35/2

submit your manuscript in $\square$ 
(exaggerated response to noxious stimuli), and allodynia (increased sensitivity to innocuous stimuli). ${ }^{2,3}$ The molecular pathogenesis that underlies the development and progression of PDN remains poorly understood. ${ }^{4}$ Current evidence-based treatment protocols recommend the use of $\alpha 2 \delta$ calcium channel blockers (gabapentin and pregabalin), anti-convulsants (such as phenytoin, carbamazepine), and antidepressants (tricyclic and selective serotonin-norepinephrine inhibitors) for symptomatic control. ${ }^{5}$ However, these treatments do not target the patho-mechanism of PDN and often do not provide sufficient pain relief. ${ }^{6}$ As a result, only a third of PDN patients achieve satisfactory pain relief. ${ }^{7}$ There is indeed an urgent need for the development of effective mechanism-specific strategy to improve current PDN management.

Accumulating body of published evidence suggests that novel inflammatory mechanisms play major roles in the development of many complications in type 2 diabetes. ${ }^{8,9}$ Specific animal studies have demonstrated that elevated levels of systemic cytokines activate cellmediated tissue inflammation involving macrophages, $\mathrm{T}$ and $\mathrm{B}$ lymphocytes, and antigen-presenting dendritic cells through autocrine, paracrine, or endocrine fashion in type 2 diabetes. ${ }^{10,11}$ Pro-inflammatory cytokines, including tumor necrosis factor (TNF)- $\alpha$, interleukin (IL)-1, IL-6, nerve growth factor (NGF), and prostaglandins, directly and indirectly, mediate many neurological diseases. ${ }^{12}$ Previously, we reported increased inflammatory reactions in the skin and peripheral sensory nerve fibers of $\mathrm{db} / \mathrm{db}$ mouse, a murine model of PDN from type 2 diabetes. $^{13}$ Our studies demonstrated an upregulation of NGF expression, as well as activation of its high-affinity receptor, tropomyosin receptor kinase (Trk) A and p38 in lumbar dorsal root ganglion (LDRG) during the period of pain behaviors. This signaling pathway enhances the expression of pro-inflammatory $\mathrm{TNF}-\alpha$, cyclooxygenase 2 , and inducible nitric oxide synthases (iNOS) expression in medium and small-sized nociceptive LDRG neurons during the period of mechanical allodynia. ${ }^{13,14}$ Subsequently, we published evidence that suggests these pro-inflammatory events cause increased numbers of skin dendritic cells, including CD207-positive Langerhans's cells (LCs) and CD68-positive dermal dendritic cells (DDCs), which are in contact with intraepidermal nociceptive nerves in hind footpad skin. ${ }^{15}$ These findings suggest that targeting this cytokine-mediated neurogenic inflammation could be an effective approach for treating PDN.
In the current study, we study the role of IL-10, an antiinflammatory cytokine, in the pathogenesis of neurogenic inflammation. IL-10, a known immunomodulator of the anti-inflammatory process, is widely expressed in the peripheral nervous tissues, including DRG neurons and peripheral nerves. ${ }^{16-18}$ Both LCs and DDCs express IL-10 receptors and respond to IL-10 to regulate skin immunoreactions. ${ }^{19,20}$ We hypothesize that neuronal IL10 downregulation contributes to the increased levels of pro-inflammatory mediators and activations of skin LCs and DDCs in PDN. Our results provide evidence that enhancement of IL-10 actions could be an effective strategy for treating PDN of type 2 diabetes.

\section{Materials and Methods Animals}

Male C57BLKS $\mathrm{db} / \mathrm{db}$ mice were obtained from Jackson Laboratories (Bar Harbor, Maine). The homozygous (db/ $\mathrm{db}$ ) mouse was used as a model of type 2 diabetes, while the heterozygous mouse $(\mathrm{db} /+)$ served as the non-diabetic control. All procedures were performed following protocols established by the Animal Models of Diabetic Complications Consortium (AMDCC; http://www.amdcc.org). All protocols were approved by the Use and Care of Animals Committee at the University of Michigan (UCUCA, protocol $\# 10,112)$. The animals' suffering and the number of animals used were minimized with all possible effort.

\section{IL-10 Treatment}

Recombinant mouse IL-10 $(0.1 \mathrm{mg} / \mathrm{kg}$ in $50 \mu \mathrm{L}$ saline, Sigma-Aldrich, St Louis, MO, USA) or saline control of the same volume was administered intraperitoneally to 8 -wk-old $\mathrm{db} /+$ and $\mathrm{db} / \mathrm{db}$ mice every other day for $2 \mathrm{wk}$ until they reached $10 \mathrm{wk}$ of age. According to its body weight, each mouse was injected with $2.5-4 \mu \mathrm{g}$ of IL10 per injection. This dose has been reported effective in other published studies. ${ }^{21-23}$ Body weight, fasting glucose, and mechanical and thermal thresholds were monitored weekly until the end of the study when tissues were collected for gene and protein analysis. All experiments and data analysis were performed in a blinded fashion.

\section{Blood Chemistry}

The onset of diabetes was confirmed by measuring blood glucose levels after $10 \mathrm{hr}$ of fasting. One drop of tail blood was tested using a glucometer (One Touch Profile, LIFESCAN, Inc., Milpitas, CA, USA) to determine the 
development of diabetes. Fasting insulin levels were obtained by using a rat/mouse insulin ELISA Kit (Linco Research, St. Charles MO, USA, \#EZRMI-13K). Fasting triglyceride levels were measured by radioimmunoassay in the Chemistry Core of Michigan Diabetes Research and Training Center (MDRTC).

\section{Mechanical Threshold Measurement}

Von Frey filaments were used to examine mechanical allodynia in the hind paws of $\mathrm{db} / \mathrm{db}$ and $\mathrm{db} /+$ mice using the up-down method. ${ }^{24}$ Specifically, mice were placed in a transparent plastic box with a metal mesh floor. A series of calibrated monofilaments (von Frey hairs; Stoelting, Wood Dale, IL, USA) with strengths from 1 to $4 \mathrm{~g}$ were applied to the plantar surface of the hind foot paws until bending. A positive response was recorded when the mechanical stimulation indued a brisk withdrawal response. One g filament was first used. Larger $(1.4 \mathrm{~g}, 2$ $\mathrm{g}$, and $4 \mathrm{~g}$ ) filaments were then used if no response was detected. Smaller filaments were used if positive responses were achieved. The stimulations were separated by $10-\mathrm{min}$ intervals to allow animals to recover between tests. Fifty percent gram threshold was determined according to Chaplan et al. ${ }^{25}$ Mechanical allodynia was determined if the mean $50 \% \mathrm{~g}$ threshold of the tested group was significantly less than that control group. All experiments and data analysis were performed in a blinded fashion.

\section{Thermal Threshold Measurement}

Nociceptive heat thresholds were evaluated using a Tail Flick Analgesia Meter (IITC Life Science, Woodland Hills, CA, USA). The mice were placed in an acrylic restrainer and the tail exposed to a pre-focused halogen light source $\left(25^{\circ} \mathrm{C}\right.$ to $\left.70^{\circ} \mathrm{C}\right)$, at a temperature determined to be innocuous in controls over the course of $20 \mathrm{sec}$ with a cut-off time of $10 \mathrm{sec}$ to prevent tissue damage. The response time for each group is averaged and statistically analyzed. $^{26}$ All experiments and data analysis were performed in a blinded fashion.

\section{Immunoblots}

L4-6 DRG was dissected from 8 mice per condition $(\mathrm{db} /+$ and $\mathrm{db} / \mathrm{db}$ mice) under deep anesthesia. Tissues were homogenized in ice-cold Tissue Protein Extraction Reagent (T-PER, Pierce Biotechnology, Rockford, IL, USA) containing protease inhibitors (Sigma Life Science, St. Louis, MO, USA). The protein concentrations of lysates were determined with $\mathrm{D}_{\mathrm{C}}$ Protein Assay Reagents
(Bio-Rad). Fifty $\mu \mathrm{g}$ of protein was boiled in $2 \mathrm{X}$ sample buffer, separated by electrophoresis on a SDS-PAGE gel, and transferred to a PVDF membrane. The membrane was blocked with $3 \%$ BSA in TBS with $0.1 \%$ Tween 20 overnight at $4{ }^{\circ} \mathrm{C}$ with primary antibody against IL-10 (1:1000, Abcam, Cambridge, MA, USA) or actin (1:5000, Santa Cruz Biotechnology, Santa Cruz, CA, USA) followed by rinsing and incubation with a corresponding secondary antibody conjugated with horseradish peroxidase (Santa Cruz) at room temperature for $2 \mathrm{~h}$. Signals were visualized using SuperSignal West Femto maximum sensitivity substrate (Pierce), captured using the Chemidoc XRS system. The density of each band was analyzed by Quantity One software (Bio-Rad). Fold changes to the corresponding control values were calculated. All experiments and data analysis were performed in a blinded fashion.

\section{DRG Immunohistochemistry}

Eight $\mathrm{db} /+$ and $\mathrm{db} / \mathrm{db}$ mice from each group were perfused with $2 \%$ paraformaldehyde in phosphate-buffered saline (PBS, pH 7.2, $0.1 \mathrm{M}$ ) under deep anesthesia. L4-L6 DRG were collected and post-fixed in $2 \%$ paraformaldehyde overnight at $4^{\circ} \mathrm{C}$, processed in graded sucrose solutions (5-30\% in PBS), and embedded in mounting media (OCT) by rapid-freezing in liquid nitrogen. Tissue sections (10 $\mu \mathrm{m})$ were mounted onto SuperFrost Plus slides (Thermo Fisher Scientific, Waltham, MA, USA). For immunolocalization, slides were rinsed with PBS and blocked in $0.1 \%$ TX-100 and 5\% non-fat dry milk in PBS. Sections were then incubated with primary antibody: IL-10 (1:1000, Abcam) at room temperature for 16-24 h. Sections were then rinsed and incubated with an Alexa Fluor 594-conjugated secondary antiserum in blocking solution (1:5000, Santa Cruz) and Alexa Fluor 488conjugated anti-NeuN antibody (1:250, Neuronal Nuclei, Millipore, Temecula, CA, USA). Sections were mounted with ProLong ${ }^{\circledR}$ Gold antifade reagent (Invitrogen) and examined under an Olympus FluoView 500 laser scanning confocal microscope. Another set of sections were incubated with primary antibody for IL-10 alone to ensure specificity and confirm no nonspecific immunoreactions.

The number of immunoreactive neuronal profiles was counted using images of LDRG sections captured with a Nikon camera (Nikon Microphoto-FXA) and MetaMorph (Molecular Devices, Sunnyvale, CA, USA, version 6.14). Cell size distribution studies were performed with measurements from $8 \mathrm{LDRG}$ from each animal. Every tenth section was selected from a series of 
consecutive LDRG sections, and a total of three to four sections were counted for each LDRG. The percentage of immune-positive neurons was determined by measuring the number of immune-positive neurons and multiplying by 100 and divided by the total number of NeuN-positive neurons. $^{27}$ All experiments and data analysis were performed in a blinded fashion.

\section{Hind Footpad Immunohistochemistry}

Eight mice were used for each group. Under deep anesthesia, hind footpads were collected and fixed by $4^{\circ} \mathrm{C}$ in Zamboni's solution ( $2 \%$ paraformaldehyde, $0.2 \%$ picric acid in $0.1 \mathrm{M}$ phosphate buffer). The tissues were rinsed in $30 \%$ sucrose in PBS overnight, cryo-embedded in mounting media, and sectioned at $30 \mu \mathrm{m}$ thick. Sections were incubated at room temperature for 16-24 $\mathrm{h}$ with primary antibodies: CD207 (1:1000, Abcam), iNOS (1:500, Abcam), and CD68 (1:200, Lifespan Biosciences, Seattle, WA, USA). Sections were then incubated with secondary antisera conjugated with different fluorophores (Alexa Fluor 488, or 594, Invitrogen, Carlsbad, CA, USA), and mounted with ProLong ${ }^{\circledR}$ Gold antifade reagent (Invitrogen). Fluorescent images were collected on an Olympus FluoView 500 confocal microscope. Approximately forty images with $0.5 \mu \mathrm{m}$ thickness per stack were flattened using the MetaMorph software. Six sections were measured for each footpad. Cell density data were presented as the mean number of cells per linear mm of epidermis from a total of 12 sections per animal. All experiments and data analysis were performed in a blinded fashion.

\section{Real-Time RT-PCR}

The experiments were performed using a published methodology. ${ }^{28}$ Total RNA was extracted from L4-6 LDRG using the RNeasy Kit (Qiagen, Valencia, CA). Six DRG (bilateral L4-6) were used from each animal with a total of 8 animals were used per condition. Reverse transcription was performed using the iScript cDNA Synthesis Kit (Bio-Rad). Reaction conditions were $5 \mathrm{~min}$ at $25^{\circ} \mathrm{C}, 30 \mathrm{~min}$ at $42^{\circ} \mathrm{C}$, and $5 \mathrm{~min}$ at $85^{\circ} \mathrm{C}$. PCR was performed using the primer sequences: NGF sense 5'-CCAAGGACGCAGCTTTCTAT-3', antisense 5'CTCCGGTGAGCTTCTGTTGAA-3'; IL-10 sense 5'-AGT ACA GCC GGG AAG ACA ATA A-3', antisense 5'-CCT GCA TTA AGG AGT CGG TTA G-3'; TNF- $\alpha$ sense 5'AGC CGA TTT GCT ATC TCA TAC CAG, antisense 5'CCT TCA CAG AGC AAT GAC TCC A; iNOS sense 5'GGG CAG CCT GTG AGA CCT T, antisense 5'-TGA GGG
CTC TGT TGA GGT CTA; GAPDH sense 5'-TCC ATG ACA ACT TTG GCA TCG TGG-3', antisense 5'-GTT GCT GTT GAA GTC ACA GGA GAC-3'. All real-time PCR reactions were carried out in 96-well PCR plates. The PCR reactions were performed with a mixture of $25 \mu \mathrm{L}$ solution containing 1X SYBR Green iCycler iQ mixture (Bio-Rad), $0.2 \mu \mathrm{M}$ of each forward and reverse primer, and cDNA preparation. The PCR amplification was carried out at $94^{\circ} \mathrm{C}$ for $2 \mathrm{~min}$, followed by 35 cycles of denaturation at $94^{\circ} \mathrm{C}$ for $30 \mathrm{~s}$, annealing at $60^{\circ} \mathrm{C}$ for $1 \mathrm{~min}$, and extension at $72^{\circ} \mathrm{C}$ for $5 \mathrm{~min}$. The fluorescence signals were detected using iCycler iQ Real-time Detection System (Bio-Rad). The quality of PCR products was determined by melting curve analysis. The fluorescence threshold value was calculated by the iCycler iQ system software. Expression levels were normalized to values obtained for GAPDH. Fold changes to the corresponding control values were calculated. All experiments and data analysis were performed in a blinded fashion.

\section{Data Presentation and Statistical Analyses}

All data are processed by Prism software (GraphPad Software, San Diego, CA, USA) and presented as group means \pm SEM. The data between the two groups were analyzed using the Mann-Whitney test. Statistical comparisons between multiple groups were made by a one-way ANOVA test followed by a post hoc Tukey's multiple comparison test. A p-value of less than 0.05 was considered statistically significant.

\section{Results}

IL-I 0- Expression is Decreased in Dorsal Root Ganglion Neurons of $\mathrm{db} / \mathrm{db}$ Mice During the Period of Pain Behavior

Previously, we reported that $\mathrm{db} / \mathrm{db}$ mice develop mechanical allodynia at $8 \mathrm{wk}$ of age. ${ }^{14}$ The pain behavior peaks at $10 \mathrm{wk}$ of age and resolves at $16 \mathrm{wk}$ of age. ${ }^{14}$ To study the role of IL-10 in PDN of type 2 diabetes, we first examined the time course of IL-10 expression in LDRG of $\mathrm{db} /+$ and $\mathrm{db} / \mathrm{db}$ mice at $5,8,10$, and 16 wk of age. During this period, we studied IL-10 protein expression by immunoblotting procedures (Figure 1A). Actin bands on the same lanes were used as loading controls. In the representative image demonstrated in Figure 1A, similar densities of IL-10 bands were detected in $\mathrm{db} /+$ and $\mathrm{db} / \mathrm{db}$ LDRG at $5 \mathrm{wk}$ of age (Figure $1 \mathrm{~A}$ ). In contrast, reduced IL-10 band densities were detected at 8 and 10 wk of age in $\mathrm{db} / \mathrm{db}$ mice, compared to $\mathrm{db} /+$ mice of the same age. IL-10 band density of $\mathrm{db} / \mathrm{db}$ mice returned to 
that of the control db/+ level at 16 wk of age (Figure 1A). The densitometric analysis demonstrated a significant reduction of IL-10 expression, with $56 \%$ at $8 \mathrm{wk}(\mathrm{p}<0.01)$ and $65 \%$ at 10 wk of age $(\mathrm{p}<0.001)$, in LDRG of $\mathrm{db} / \mathrm{db}$ mice, compared to $\mathrm{db} /+$ mice of the same age (Figure $1 \mathrm{~B}$ ). In parallel, IL-10 gene expression of $\mathrm{db} / \mathrm{db}$ LDRG were decreased to $53 \%$ at $8 \mathrm{wk}(\mathrm{p}<0.01)$ and $52 \%$ at $10 \mathrm{wk}$ of age $(\mathrm{p}<0.01)$ of the control db/+ levels by RT-PCR (Figure $1 C)$. This downregulation of DRG IL-10 protein (Figure $1 \mathrm{~A}$ and B)and gene (Figure 1C) expression in $\mathrm{db} / \mathrm{db}$ mice resolved by 16 wk of age (Figure $1 \mathrm{~B}$ and $\mathrm{C}$ ).

To determine the neuronal populations that express IL10 in DRG, double immunofluorescent studies were performed with antisera for IL-10 and NeuN, a neuronal marker. As demonstrated in Figure 2, expression of IL10 protein was detected in DRG neurons of both $\mathrm{db} /+$ and $\mathrm{db} / \mathrm{db}$ mice at $10 \mathrm{wk}$ of age (Figure 2 ). The numbers of IL10 -positive neurons are reduced in $\mathrm{db} / \mathrm{db}$ mice, compared to those of $\mathrm{db} /+$ mice (compare Figure $2 \mathrm{~A}-\mathrm{D}$ ). IL-10 immunoreactivity was detected in both large-sized $(>40$ $\mu \mathrm{m}$ in diameter, Figure $2 \mathrm{~A}$, arrow) $\mathrm{DRG}$ neurons and small- to medium-sized DRG neurons $(<40 \mu \mathrm{m}$ in diameter, Figure $2 \mathrm{~A}$, arrowheads) in $\mathrm{db} /+$ mice. In contrast, most of the IL-10 immunoreactivity was detected in largesized (Figure 2D, arrows) but not small- to medium-sized DRG neurons (Figure 2D, arrowhead) in $\mathrm{db} / \mathrm{db}$ LDRG.
Quantification analysis revealed the percentages of IL-10positive LDRG neurons were reduced in $\mathrm{db} / \mathrm{db}$ mice, compared to $\mathrm{db} /+$ at 8 and 10 wk of age (Figure $2 \mathrm{G}, \mathrm{p}<$ 0.0001$,$) . This difference was not detected at 5$ and $16 \mathrm{wk}$ of age. The cell-size distribution analysis demonstrated significantly smaller percentages of small- to mediumsized IL-10-positive DRG neurons in $\mathrm{db} / \mathrm{db}$ mice compared to those of $\mathrm{db} /+$ (Figure $2 \mathrm{H}, \mathrm{p}<0.0001$ ) at $10 \mathrm{wk}$ of age (Figure $2 \mathrm{H}, \mathrm{p}<0.01$ ). In contrast, percentages of IL-10-positive large-sized DRG neurons were higher in $\mathrm{db} / \mathrm{db}$ compared to $\mathrm{db} /+$ mice (Figure $2 \mathrm{H}, \mathrm{p}<0.01$ ) at this stage. Our results support that there is a significant reduction of IL-10-positive small- and medium-sized LDRG in $\mathrm{db} / \mathrm{db}$ mice compared to $\mathrm{db} /+$ mice during the period of pain behavior.

\section{IL-I0 Treatment Alleviates Pain Behaviors in $\mathrm{db} / \mathrm{db}$ Mice}

To study the biological significance of IL-10 downregulation in PDN, we next examined the effects of exogenous IL10 administration on the mechanical and thermal thresholds of $\mathrm{db} /+$ and $\mathrm{db} / \mathrm{db}$ mice after the development of allodynia starting at $8 \mathrm{wk}$ of age. Recombinant mouse IL-10 (0.1 mg/ $\mathrm{kg}$ in $50 \mu \mathrm{L}$ saline) was administered to both $\mathrm{db} /+$ (IL-10 $\mathrm{db} /+$ ) and $\mathrm{db} / \mathrm{db}(\mathrm{IL}-10 \mathrm{db} / \mathrm{db}$ ) mice every other day for 2 wk starting at $8 \mathrm{wk}$ of age (Figure $3 \mathrm{~A}$ and $\mathrm{B}$ ). The control
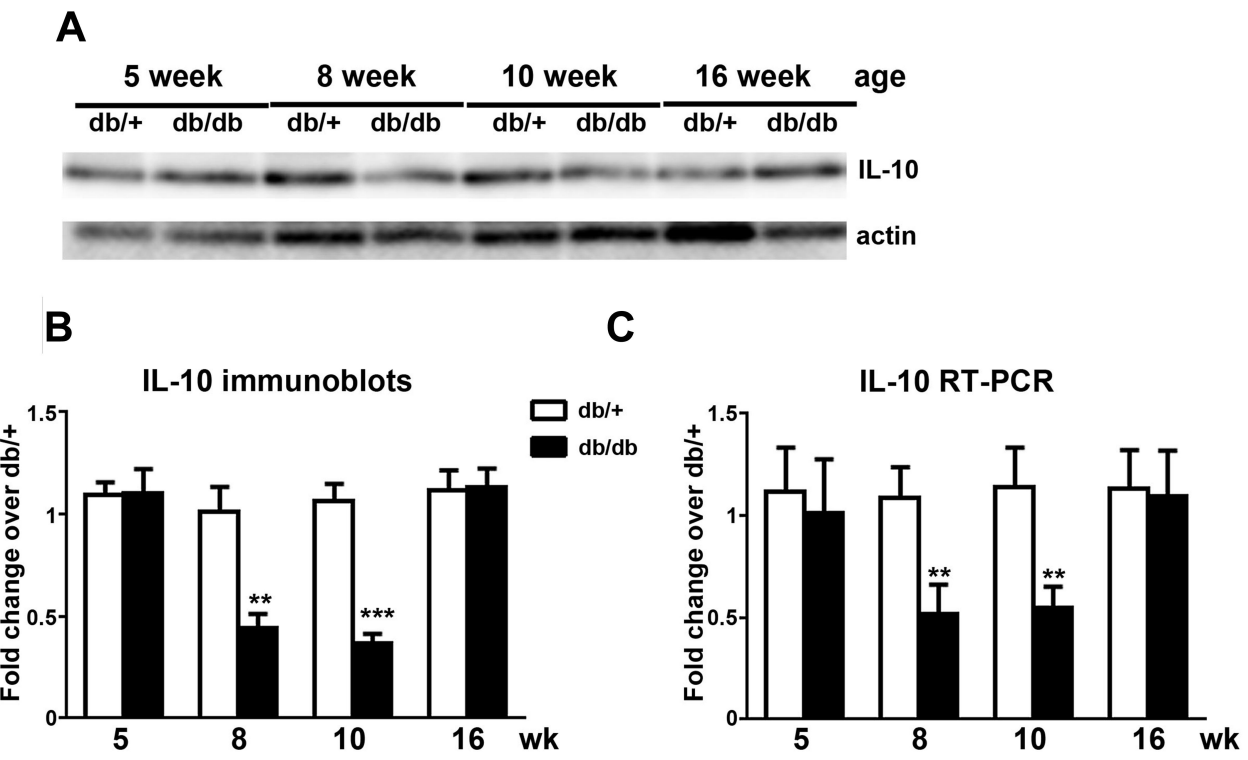

Figure I Reduced IL-I0 protein and gene expression in LDRG neurons of db/db mice during the period of pain behavior, (A): Representative immunoblots of IL-I0 and actin using LDRG extracts from $\mathrm{db} /+$ and $\mathrm{db} / \mathrm{db}$ mice at 5, 8, I0, and 16 wk of age. Actin immunoblots were used as loading controls. (B): Densitometric analysis of IL-I0 immunoblots from 5, 8, 10, and 16 wk of age. The data were normalized to the band densities of db/+ mice of the same age. (C): Results of IL-I0 RT-PCR using LDRG from $\mathrm{db} /+$ and $\mathrm{db} / \mathrm{db}$ mice at $5,8,10$, and 16 wk of age. The data of $\mathrm{db} / \mathrm{db}$ mice were normalized with the data of $\mathrm{db} /+$ mice at the same age. $\mathrm{N}=8 \mathrm{for}$ each group. $* * \mathrm{p}<0.0 \mathrm{I}$; $* * * \mathrm{p}<0.00 \mathrm{I}$, analyzed by Mann-Whitney test. 

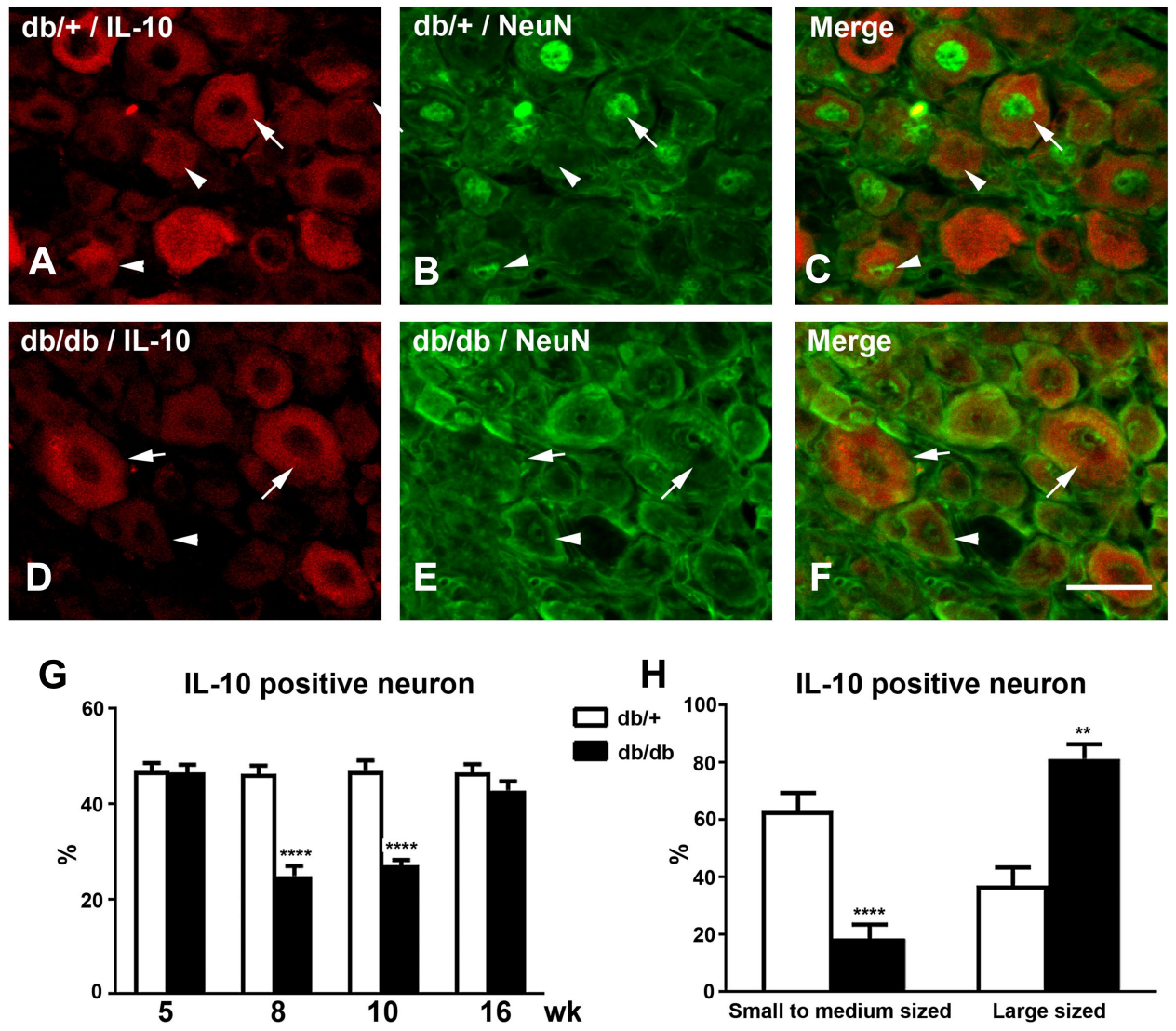

H

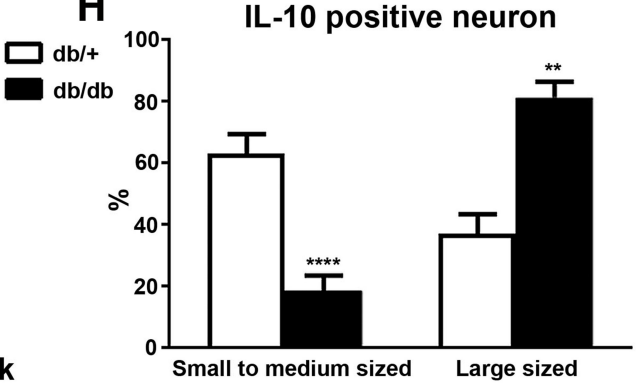

Figure 2 Reduced numbers of IL-10-positive LDRG neurons in $\mathrm{db} / \mathrm{db}$ mice during the period of pain behavior Representative confocal microscopic images of double immunofluorescent studies for IL-I0 (A, db/+; D, db/db) and NeuN (B, db/+; E, db/db), or merged (C, db/+; F db/db) at 8 wk of age. (A-C): IL-I0 immunoreactivity was detected in both large-sized (arrows) and small- to medium-sized (arrowheads) DRG neurons in db/+ mice. (D-F): IL- 10 immunoreactivity was only detected in large-sized LDRG neurons (arrows) but not small- to medium-sized neurons (arrowheads) in db/db mice. Bar $=50 \mu m$. $N=8$. (G): Percentages of IL- I0-positive LDRG neurons in db/+ and db/db mice from 5-16 wk of age. (H): Percentages of small- and medium-sized and large-sized IL-I0-positive DRG neurons in db/+ and db/db mice at I0 wk of age. ** $\mathrm{p}<$ $0.01 ; * * * * p<0.0001$, analyzed by Mann-Whitney test.

A

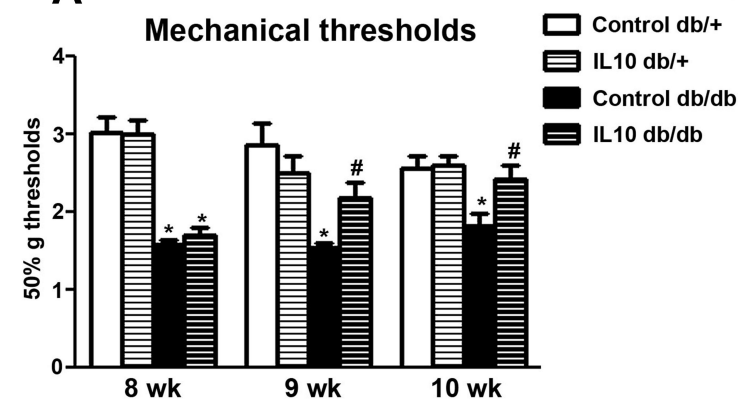

B

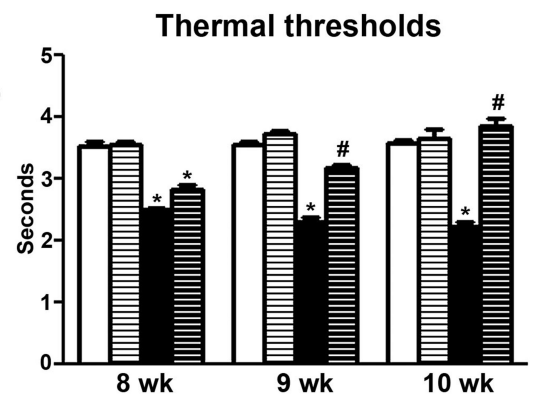

Figure 3 IL- 10 treatment reduces both mechanical allodynia and thermal hyperalgesia in $\mathrm{db} / \mathrm{db}$ mice. (A): Mean mechanical thresholds of control and IL- 10 -treated db/+ and db/db mice. Reduced mean mechanical thresholds were detected on control db/db mice at 8 and $10 \mathrm{wk}$ of age, compared to those of control $\mathrm{db} /+$ mice of the same age. The mean mechanical thresholds of IL- $10 \mathrm{db} / \mathrm{db}$ mice were significantly elevated after I (at $9 \mathrm{wk}$ of age) and $2 \mathrm{wk}$ (at I0 wk of age) of IL- 10 treatment, compared to those of control db/db mice of the same age. In contrast, IL-10 treatment did not affect the mean mechanical thresholds of $\mathrm{db} /+$ mice. $\mathrm{N}=8$. ${ }^{*} \mathrm{p}<0.00 \mathrm{I}$, compared to $\mathrm{db} /+$ mice of the same age; ${ }^{\#} \mathrm{p}<0.05$ compared to control db/db mice of the same age, analyzed by Mann-Whitney test. (B) Mean thermal thresholds of control and IL-I0-treated db/+ and db/db mice. Significantly reduced mean thermal thresholds were detected in control $\mathrm{db} / \mathrm{db}$ mice at 8 and 10 wk of age, compared to those of control $\mathrm{db} /+$ mice of the same age. The mean thermal thresholds of IL- $10 \mathrm{db} / \mathrm{db}$ mice were significantly elevated after I (at $9 \mathrm{wk}$ of age) and $2 \mathrm{wk}$ (at I0 wk of age) of IL- 10 treatment, compared to those of control db/db mice. $\mathrm{N}=8$. * $\mathrm{p}<0.00 \mathrm{I}$, compared to $\mathrm{db} /+$ mice of the same age; ${ }_{\mathrm{p}}^{\mathrm{P}}<0.05$ compared to control $\mathrm{db} / \mathrm{db}$ mice at the same time point, analyzed by Mann-Whitney test. 
$\mathrm{db} /+$ and $\mathrm{db} / \mathrm{db}$ mice were treated with saline of the same volume. Mechanical and thermal thresholds were measured weekly during the duration of the study. As demonstrated in Figure 3, reduced mean mechanical thresholds were detected at $8 \mathrm{wk}$ of age in control $\mathrm{db} / \mathrm{db}$ mice $(\mathrm{p}<0.05$, Figure $3 \mathrm{~A}$ ) when compared to control $\mathrm{db} /+$ mice, confirming the development of mechanical allodynia at this time point. After $1 \mathrm{wk}$ of treatment, the mean mechanical thresholds of IL-10 $\mathrm{db} / \mathrm{db}$ mice were significantly higher than those of control $\mathrm{db} / \mathrm{db}$ mice $(\mathrm{p}<0.05$, Figure $3 \mathrm{~A}$ ), suggesting a reduction in mechanical allodynia. This trend continued duringthe second week of treatment when the mean mechanical thresholds of IL-10 $\mathrm{db} / \mathrm{db}$ mice reached the levels of the control db/+ (10 wk, Figure $3 \mathrm{~A})$. In contrast, IL-10 treatment had no effects on the mean mechanical thresholds of $\mathrm{db} /+$ mice compared to those of the control group (Figure 3A).

Similar effects of IL-10 treatment were detected on thermal thresholds in $\mathrm{db} / \mathrm{db}$ mice. Reduced mean thermal thresholds were measured at $8 \mathrm{wk}$ of age in control db/db mice ( $p<0.05$, Figure $3 \mathrm{~B}$ control) when compared to control $\mathrm{db} /+$ mice, suggesting the presence of thermal hyperalgesia in control $\mathrm{db} / \mathrm{db}$ mice. After $1 \mathrm{wk}$ of IL-10 treatment, the mean thermal threshold of IL-10-treated db/ $\mathrm{db}$ mice was elevated compared to that of control $\mathrm{db} / \mathrm{db}$ mice $(\mathrm{p}<0.05$, Figure $3 \mathrm{~B})$. This trend continued during the second week of treatment when the mean thermal threshold of IL-10-treated $\mathrm{db} / \mathrm{db}$ mice was increased to the level of control db/+ mice (10 wk, Figure 3B). IL-10 treatment had no effect on the mean thermal thresholds of IL-10 db/+ mice compared to those of control $\mathrm{db} /+$ mice of the same age (Figure 3B).

\section{IL-10 Treatment Does Not Influence Body Weight, Fasting Blood Levels of Glucose, Insulin, and Triglyceride}

Diabetic parameters such as body weight, fasting levels of glucose, insulin, and triglyceride were monitored during IL-10 treatment. Glycosylated hemoglobin was not measured because it does not reflect IL-10 effects with only 2 weeks of duration. At $10 \mathrm{wk}$ of age, all parameters were elevated in control $\mathrm{db} / \mathrm{db}$ mice including mean body weight (Figure 4A, $\mathrm{p}<0.001$ ), fasting glucose (Figure $4 \mathrm{~B}, \mathrm{p}<0.001$ ), fasting insulin (Figure $4 \mathrm{C}, \mathrm{p}<001$ ), and fasting triglyceride (Figure $4 \mathrm{D}, \mathrm{p}<0.01$ ), compared to $\mathrm{db} /+$ control. After two weeks of IL-10 treatment, there were no significant changes in body weight, fasting glucose, insulin, and triglyceride levels between IL-10 treated $\mathrm{db} / \mathrm{db}$ mice and control $\mathrm{db} / \mathrm{db}$ mice. Similarly, there were no significant differences between the IL-10 $\mathrm{db} /+$ mice and control $\mathrm{db} /+$ mice.

\section{IL-I0 Treatment Reduces the Expression of Inflammatory Mediators in LDRG of $\mathrm{db} / \mathrm{db}$ Mice}

To determine the effect of IL-10 on the upregulation of proinflammatory markers in $\mathrm{db} / \mathrm{db}$ mice, ${ }^{29}$ we performed RT-PCR in LDRG after IL-10 treatment. Consistent with our previous findings, the gene expression of $\mathrm{NGF}(\mathrm{p}<$ 0.05 , Figure 5A), TNF- $\alpha(\mathrm{p}<0.05$, Figure 5B), iNOS $(\mathrm{p}<0.05$, Figure 5C), and Trk A $(\mathrm{p}<0.05$, Figure 5D) was upregulated in LDRG of control $\mathrm{db} / \mathrm{db}$ mice. Two weeks of IL-10 treatment significantly reduced the expression of NGF $(\mathrm{p}<0.05$, Figure 5A), iNOS $(\mathrm{p}<$ 0.05 , Figure 5B), TNF- $\alpha(\mathrm{p}<0.05$, Figure 5C), and Trk $\mathrm{A}(\mathrm{p}<0.05$, Figure $5 \mathrm{D})$ in $\mathrm{db} / \mathrm{db}$ mice. In contrast, IL-10 treatment did not change the gene expression of NGF, iNOS, TNF- $\alpha$, and Trk $A$ in $d b /+$ mice (Figure 5).

\section{IL- 10 Treatment Reduces the Numbers of Langerhans Cells and Dermal Dendritic Cells in $\mathrm{db} / \mathrm{db}$ Mice}

Based on our published study, increased CD-207-positive LCs and CD-68-positive DDC aggregations are detected in hind footpad skin of $\mathrm{db} / \mathrm{db}$ mice from 8 to $12 \mathrm{wk}$ of age. ${ }^{15}$ In the current study, we examine the effects of IL-10 treatment on the cellular phenomena using CD68 and CD207 immunohistochemistry (Figure 6). Cell density analysis detected increasing densities of both DDCs $(\mathrm{p}<0.01$, Figure 6A) and LCs $(p<0.01$, Figure $6 \mathrm{~B})$ in $\mathrm{db} / \mathrm{db}$ mice treated with saline at $10 \mathrm{wk}$ of age, which is consistent with our previous results. Two-week exogenous IL-10 treatment significantly reduced the densities of LCs $(\mathrm{p}<0.05$, Figure $6 \mathrm{~A})$ and DDCs $(\mathrm{p}<0.05$, Figure $6 \mathrm{~B})$ in $\mathrm{db} / \mathrm{db}$ mice. IL-10 treatment did not affect the cell densities in $\mathrm{db} /+$ mice.

\section{IL-I 0 Treatment Reduces the Numbers of iNOS-Positive Langerhans Cells in $\mathrm{db} / \mathrm{db}$ Mice}

To examine the effect of IL-10 on skin iNOS expression, we performed double immunohistochemistry of iNOS and CD-207 on hind foot pads of control and IL-10-treated db/ + and $\mathrm{db} / \mathrm{db}$ mice. As demonstrated in the representative 


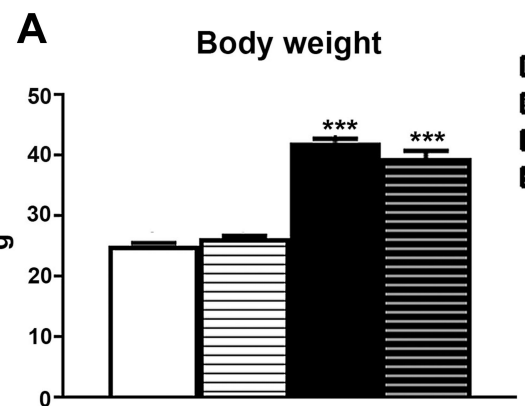

C

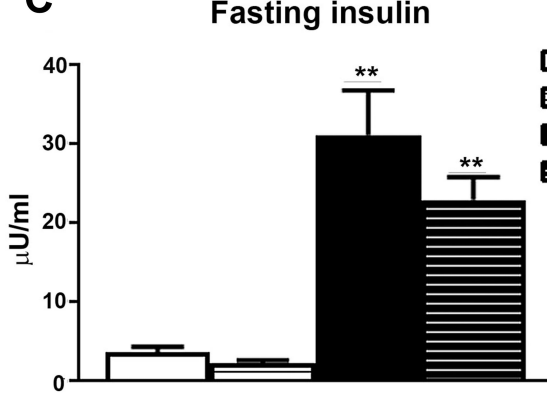

\section{B}
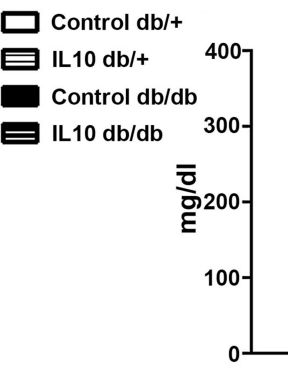

D

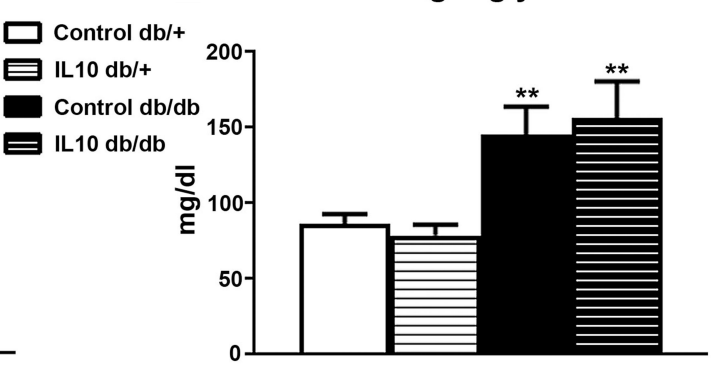

Figure 4 IL- 10 treatment did not affect metabolic parameters. The parameters of type 2 diabetes, including (A) mean body weight, (B) fasting blood glucose level, (C) fasting insulin, (D) fasting triglyceride levels were measured at the end of two-week IL- 10 treatment. IL- 10 treatment did not significantly affect the four parameters in either $\mathrm{db} /+$ or $\mathrm{db} / \mathrm{db}$ mice. $\mathrm{N}=8$. ${ }^{* *} \mathrm{p}<0.01$; ${ }^{* * *} \mathrm{p}<0.00 \mathrm{I}$, compared to control $\mathrm{db} /+$ mice, analyzed by Mann-Whitney test.

A

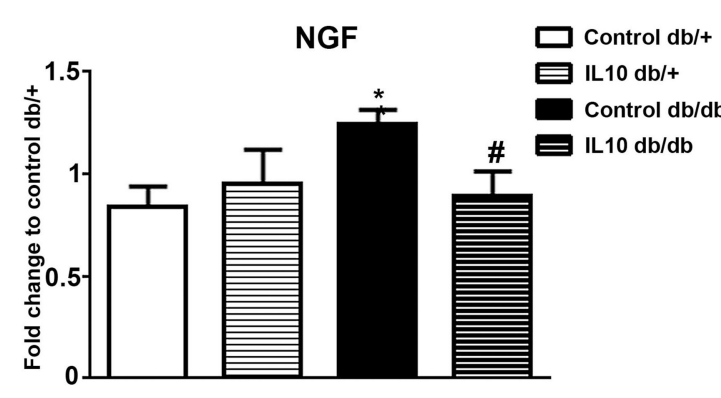

C

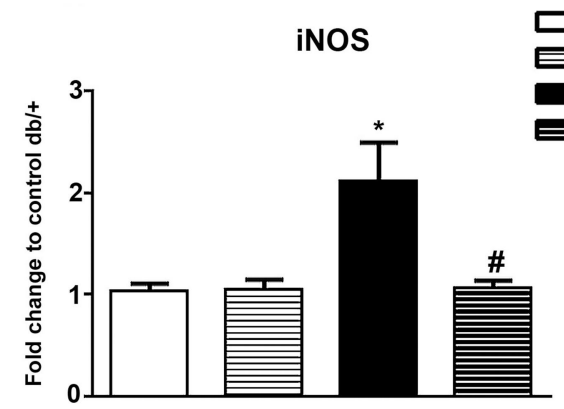

B

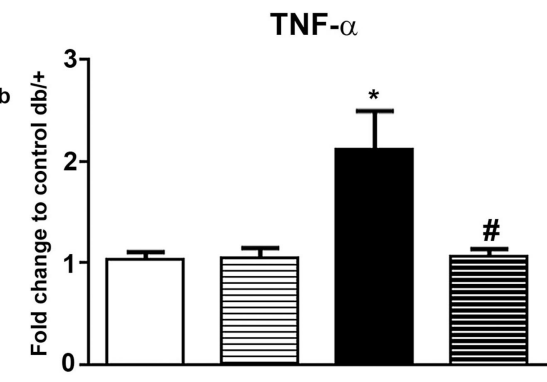

D

Control db/+

IL10 db/+

Control db/d

IL10 db/db

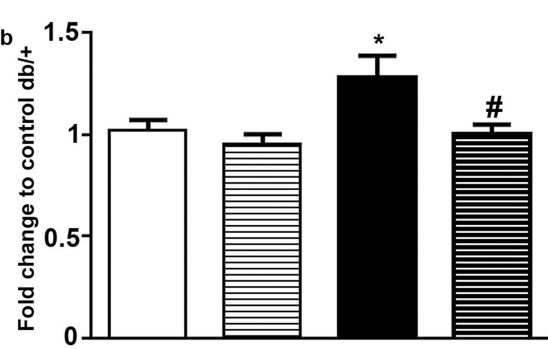

Figure 5 IL-10 treatment reduces NGF, TNF- $\alpha$, iNOS and Trk A gene upregulation in db/db mice. The gene expression levels of (A) NGF, (B) TNF- $\alpha$, (C) iNOS, (D) Trk $A$ in LDRG of $d b /+$ and $d b / d b$ mice were normalized to those of control $d b /+$ mice of the same age after two weeks of IL-I0 treatment. IL-I0 treatment significantly reduced the upregulation of gene expression in $\mathrm{db} / \mathrm{db}$ mice, but not $\mathrm{db} /+$ mice on all 4 inflammatory mediators. $\mathrm{N}=8$. ${ }^{*} \mathrm{p}<0.05 \mathrm{compared}$ to control db/+ mice; ${ }^{\#}<<0.05$, compared to control $\mathrm{db} / \mathrm{db}$ mice, analyzed by Mann-Whitney test. 
A

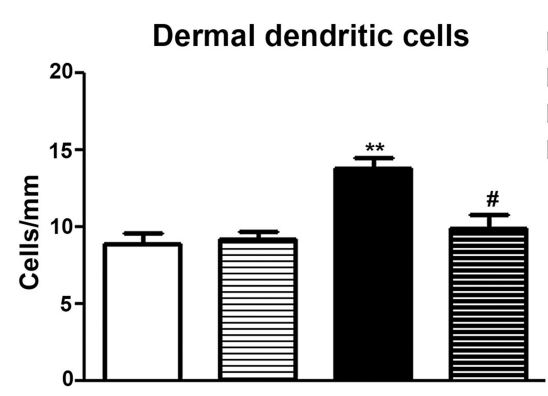

B

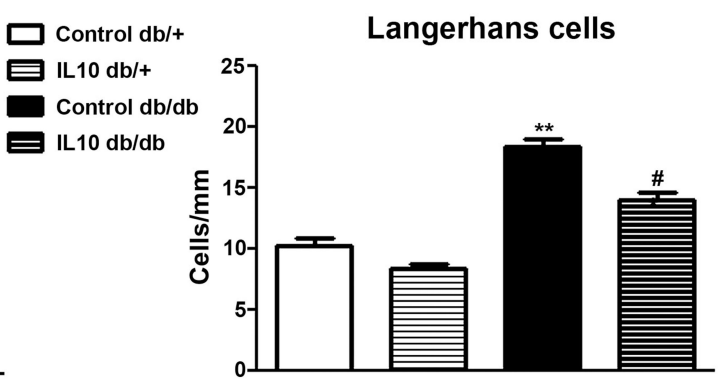

Figure 6 IL-10 treatment reduces DDCs and LCs in db/db mice. CD-68-positive DDCs and CD-207-positive LCs in hind footpad skin were detected by immunohistochemistry. Increased numbers of DDCs (A) and LCs (B) were detected in control db/db mice compared to control db/+ mice. The aggregations of both DDCs and LCs in $\mathrm{db} / \mathrm{db}$ mice were reduced by IL- 10 treatment (compare control db/db to IL- $10 \mathrm{db} / \mathrm{db}$ ). IL- 10 treatment did not affect the cell aggregations in $\mathrm{db} /+$ mice $(\mathrm{compare}$ control $\mathrm{db} /$ + mice to IL- $10 \mathrm{db} /+)$. N=8. ${ }^{* *} \mathrm{p}<0.0 \mathrm{I} ;{ }^{\#} \mathrm{p}<0.05$, compared to control db/+ mice, analyzed by Mann-Whitney test.

confocal images, increased numbers of iNOS-positive LC were detected in control $\mathrm{db} / \mathrm{db}$ mice compared to control $\mathrm{db} /+$ mice (compare Figure $7 \mathrm{~A}-\mathrm{G}$ and Figure $7 \mathrm{~B}-\mathrm{H}$ ). In $\mathrm{db} / \mathrm{db}$ mice, IL-10 treatment significantly reduced the number of iNOS- and CD-207-positive LCs in the hind footpad skin (compare Figure $7 \mathrm{G}-\mathrm{J}$, and Figure $6 \mathrm{H}-\mathrm{K}$ ). IL-10 treatment did not affect the number of iNOS- and CD207-positive LCs in footpad skin of $\mathrm{db} /+$ mice (compared Figure 7A-D; Figure 7B-E). Cell density analysis data revealed a 2-fold increase of iNOS-positive LCs in control $\mathrm{db} / \mathrm{db}$ mice, compared to control $\mathrm{db} /+$ mice $(\mathrm{p}<$ 0.01 , Figure 8 ). The increased cell density in $\mathrm{db} / \mathrm{db}$ mice was significantly reduced after IL-10 treatment. $(\mathrm{p}<0.05$, Figure 8). IL-10 treatment did not affect the iNOS-positive cell density in $\mathrm{db} /+$ mice.

\section{Discussion}

The molecular mechanism of neurogenic inflammation in PDN is not clear. In the current study, we demonstrated a reduced expression of LDRG-derived IL-10 in $\mathrm{db} / \mathrm{db}$ mice during the period of pain behavior. The current data, along with our previous results which demonstrated concomitant upregulation of pro-inflammatory pain mediators, suggest bidirectional alterations of neurogenic proinflammatory and anti-inflammatory mechanisms underlying neurogenic skin inflammation in PDN of type 2 diabetes.

The main biological effects of IL-10 are to suppress the actions of proinflammatory cytokines in dendritic cells and macrophages in the skin. ${ }^{30}$ The current data demonstrate the down-regulation of IL-10 expression during the period of pain behavior in $\mathrm{db} / \mathrm{db}$ mice. Our findings support the hypothesis that lack of IL-10 results in an unbalanced upregulation of pro-inflammatory cytokines. In support of our results, reduced IL-10 expression has been reported in various inflammatory conditions, including inflammatory bowel diseases, ${ }^{31}$ systemic lupus erythematosus, ${ }^{32}$ and cancers. ${ }^{33}$ In type 2 diabetes, a reduced IL-10 level is associated with obesity, insulin resistance, and glucose intolerance. $^{34,35}$ The Leiden 85 -plus study demonstrated a direct link between low IL-10 levels with type 2 diabetes. $^{36}$ This evidence supports our findings in $\mathrm{db} / \mathrm{db}$ mice.

In the peripheral nervous system, IL-10 and IL-10 receptors are expressed in DRG neurons. ${ }^{16}$ The role of neurogenic IL-10 in the development of PDN is still unclear. Previously, we reported similar phenomena in an animal model of metabolic syndrome. ${ }^{23}$ Our current study is the first to report that reduced endogenous DRG IL-10 action could mediate enhanced neurogenic inflammation in PDN of type 2 diabetes. In addition to antagonizing inflammation, endogenous neurogenic IL-10 could play a protective role in facilitating tissue recovery in neuropathy. Krukowski and colleagues reported inhibition of endogenous IL-10 action in DRG delayed the recovery from paclitaxel-induced mechanical allodynia. ${ }^{37}$ Taken together, IL-10 downregulation could be an important mechanism not only for the development of initial painful symptoms but also loss of sensory functions at a later stage of DN.

In contrast to the inhibitory role in PDN, IL-10 could have a different function after mechanical nerve injury. Kleinschnitz and colleagues reported increased DRG IL10 expression in a constrictive nerve injury (CCI) model. $^{18}$ Interestingly, Ruohonen and colleagues reported increased DRG IL-10 expression after CCI was also detected in the contra-lateral non-operated 

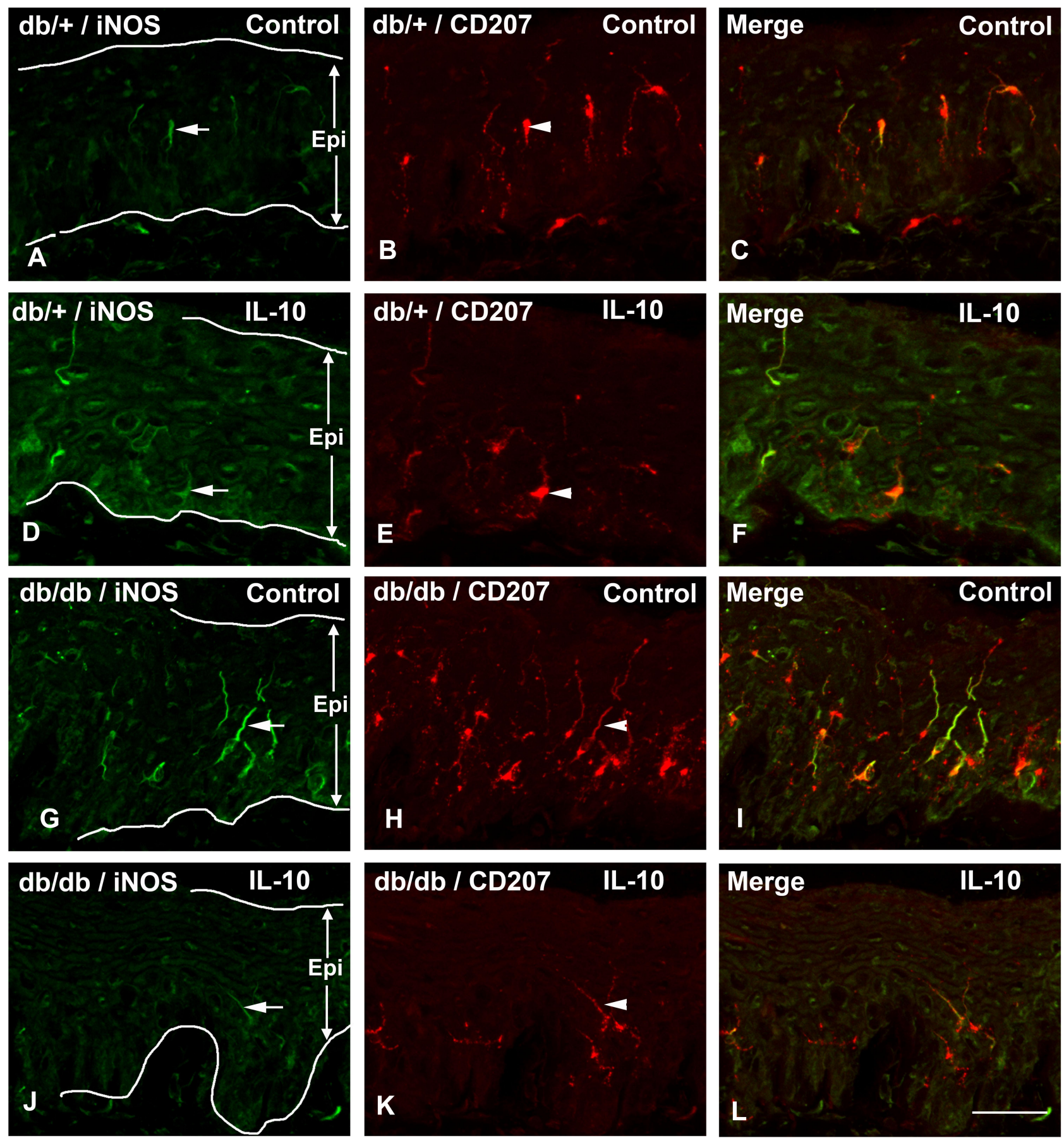

Figure 7 IL-10 treatment reduces iNOS- and CD-207-positive Langerhans cells in db/db mice. Representative confocal images of iNOS (A, D, G, J) and CD-207 (B, E, H, K) immunohistochemistry using hind footpad sections of $\mathrm{db} /+$ and $\mathrm{db} / \mathrm{db}$ mice. The images were merged together in $(\mathbf{C}, \mathbf{F}, \mathbf{I}, \mathbf{L})$ to demonstrate double immunolabelling. Most iNOS-positive cells (arrows) are also immune-positive for CD-207 (arrowheads). Increased numbers of both iNOS- and CD-207-positive LCs were detected in control $\mathrm{db} / \mathrm{db}$ mice compared to control db/+ mice (compare A-G, B-H, and C-I). IL-10 treatment reduces numbers of both iNOS and CD-207-positive cells in db/db mice (compare G-J, H-K, and I-L) but not db/+ mice (compare A-D, C-E, B-F). Bar $=50 \mu \mathrm{m}, \mathrm{N}=8$.

nerves, suggesting circulating factors from the nerve procedure could mediate this phenomenon. ${ }^{38}$ Further evidence was reported by Jancalek and colleagues that indicated IL-10 expression is significantly higher in the sham-operated groups than that of the naive animals. ${ }^{39}$
Judging from these reports, increased DRG IL-10 expression could not be specifically from nerve injury but a general reaction to the surgical procedures in CCI. The significance of this CCI-derived IL-10 upregulation is unclear. 


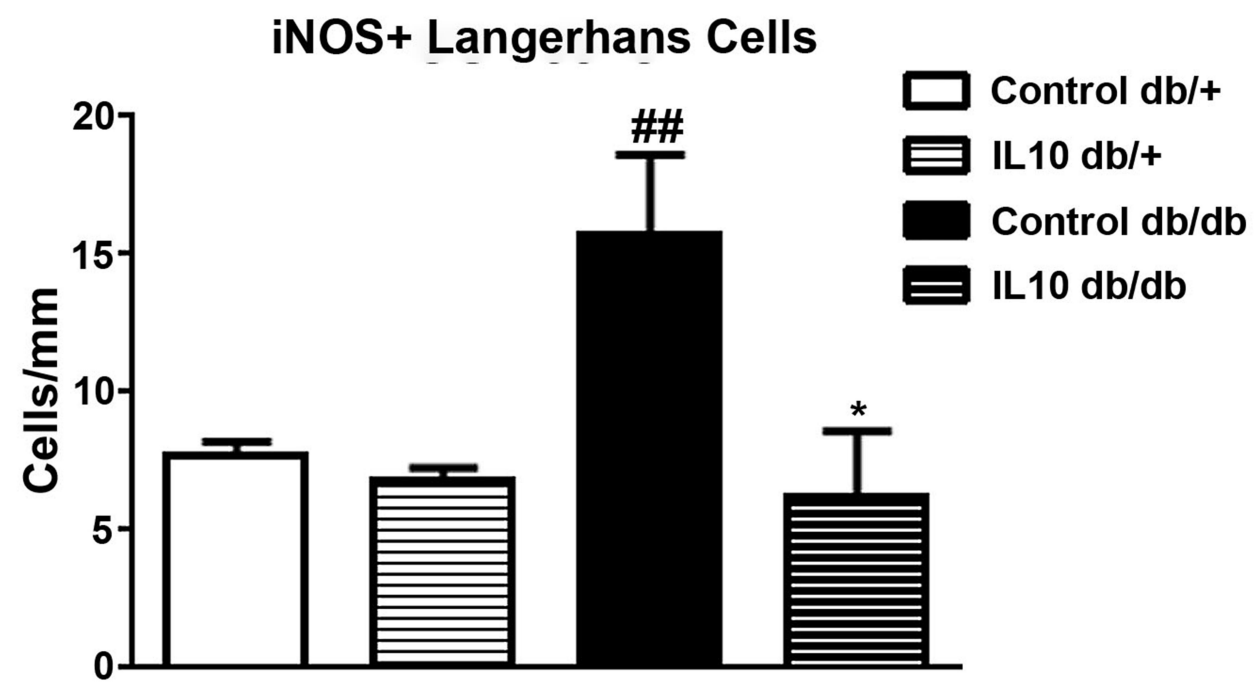

Figure 8 Cell density analysis of iNOS- and CD-207-positive Langerhans cells in hind footpads of db/+ and db/db mice after IL-10 treatment. Increased iNOS- and CD-207positive cells were detected in control db/db mice, compared to control db/+ mice. Two weeks of IL- 10 treatment significantly reduced the densities of iNOS- and CD-207 positive cells in $\mathrm{db} / \mathrm{db}$ mice. ${ }^{\#} \mathrm{p}<0.01$ compare to control $\mathrm{db} /+$ mice; ${ }^{*} \mathrm{p}<0.05$, compare to control db/db mice, analyzed by Mann-Whitney test. $\mathrm{N}=8$.

Our results suggest that the IL-10 immunoreactivity is mostly found in the medium- and small-sized DRG neurons in $\mathrm{db} /+$ mice. These neurons are responsible for nociception and are affected at an early stage of diabetes. ${ }^{14}$ In agreement with our data, Jancalek and colleagues reported expression of IL-10 immunoreactivity in small- to medium-sized neurons. ${ }^{39}$ Our results demonstrate that the loss of IL-10 immunoreactivity was detected mostly in the same neuronal groups in $\mathrm{db} / \mathrm{db}$ mice. In contrast, increased percentages of IL-10-positive large DRG neurons in $\mathrm{db} / \mathrm{db}$ mice could suggest a compensatory mechanism in response to the reduction of IL-10 expression in small to medium-sized neurons and elevated inflammation. A similar phenomenon was detected in constrictive nerve injury models. ${ }^{16,17}$ These findings, coupled with our previous reports that demonstrate increased expression of proinflammatory mediators in these specific cell populations of $\mathrm{db} / \mathrm{db}$ mice, ${ }^{13,14}$ suggesting autocrine or paracrine mechanisms in the regulation of cytokine expression in DRG neurons of $\mathrm{db} / \mathrm{db}$ mice. $^{13,14,29}$

In the current study, administration of IL-10 significantly reduces mechanical allodynia and thermal hyperalgesia in $\mathrm{db} / \mathrm{db}$ mice. Exogenous IL-10 administration has been reported to be beneficial in neuronal functions after traumatic and excitotoxic spinal cord injury. ${ }^{40,41}$ In addition, IL-10 treatment protects neurons from ischemia damage from stroke ${ }^{42}$ and programmed cell death in cerebellar granular cells. ${ }^{43}$ In support of our results,
Kanaan and colleagues demonstrated that IL-10 administration alleviates endotoxin-induced hyperalgesia in inflammatory pain by reducing TNF- $\alpha$ and NGF expression. ${ }^{44}$ Furthermore, several other published studies reported that exogenous IL-10 administration improves neuropathic pain after nerve injury and spinal cord injury. ${ }^{45,46}$ Overexpression of the IL-10 gene in spinal cord improves neuropathic pain. ${ }^{47,48}$ Similar IL10 benefits were reported in our previous study in highfat-diet-induced neuropathy. ${ }^{23}$ There are several potential mechanisms for IL-10 mediated analgesia. First, IL-10 treatment decreases cytokine-mediated inflammation, a common phenomenon in various neuropathic pain models. Second, IL-10 reduces the expression of voltage-gated sodium channels in DRG neurons. ${ }^{49}$ Third, exogenous IL-10 also has a potential neurotrophic action that protects neurons from programmed cell death. ${ }^{50}$

The anti-inflammatory action of IL-10 has been widely reported in various systems. Specifically related to our study, IL-10 treatment reduced both neuronal NGF and TNF- $\alpha$ expression with an improvement of hyperalgesia in an endotoxin-induced mouse pain model. ${ }^{44}$ In an animal model of trigeminal neuralgia, recombinant IL-10 treatment reduced pain by suppressing a neuronal pain mediator, CXCL-2, expression in trigeminal ganglia. ${ }^{51}$ These studies are in support of our data that systemic IL-10 administration can effectively reduce neurogenic proinflammatory mediators in sensory neurons and painful symptoms. 
We determined that IL-10 treatment significantly reduced skin LC and DDC aggregations. The IL-10-mediated anti-inflammatory effect on skin cellular immunity has not been well studied. In support of our results, exogenous IL-10 from nanocomposites reduces TNF- $\alpha$ and IL- $1 \beta$ gene expression and macrophage activation in a 3-dimensional in vitro skin model. ${ }^{52}$ Beissert, Chatelain, and their groups reported exogenous IL-10 reduces the antigen-presenting abilities, and ICAM-1 expression of LC and DDC to reduce the activation of Th1 cells and skin inflammation. ${ }^{53,54}$

Langerhans cells express iNOS and serve as a major source of $\mathrm{NO}$ in the skin. ${ }^{55,56}$ Activation of the nitric oxide pathways in skin cells, including keratinocytes, melanocytes, Langerhans cells, fibroblasts, and endothelial cells, are important mechanisms underlying skin inflammation. ${ }^{56}$ Our findings suggest that increased densities of iNOS-positive LCs increase skin NO levels to activate the neurogenic skin inflammation in PDN. In support of this hypothesis, Mowbray and colleagues reported that an exogenous application of NO donors induces an intense epidermal infiltrate of macrophages with similar dermal infiltrates of CD3-, CD4-, CD8-, and CD68-positive cells and neutrophils. ${ }^{57} \mathrm{Cruz}$ and colleagues demonstrated that dendritic cell-derived NO directly triggers skin inflammation after applications of contact sensitizers and irritants. ${ }^{58}$ These reports, along with our findings, support that NO from iNOS-positive LCs mediates skin immunoreactions during the development of pain behavior in $\mathrm{db} / \mathrm{db}$ mice.

\section{Conclusion}

In summary, our current results demonstrate that reduced IL-10 expression in DRG neurons could be an important mechanism for the enhanced pro-inflammatory cytokine expression and skin cellular immunoreactions in PDN of type 2 diabetes. Our current findings support the administration of IL-10 could be an effective treatment for PDN by reducing the neurogenic inflammation in DRG neurons and skin.

\section{Abbreviations}

DDC, dermal dendritic cell; iNOS, inducible nitric oxide synthase; IL, interleukin; LC, Langerhans cell; LDRG, lumbar dorsal root ganglion; NGF, nerve growth factor; PDN, painful diabetic neuropathy; Trk, tropomyosin receptor kinase; TNF, tumor necrosis factor.

\section{Acknowledgments}

This study is supported by National Institutes of Health 1K08NS061039.

The authors thank Dr. Eva L Feldman for her mentorship and support, John Hayes, Yu Hong, and Sang Su Oh for technical assistance. This work utilized the Morphology and Image Analysis Core of the Michigan Diabetes Research and Training Center funded by NIH (5P60 DK20572) from the National Institute of Diabetes \& Digestive \& Kidney Diseases.

\section{Disclosure}

The authors report no conflicts of interest in this work.

\section{References}

1. Boulton AJ, Vinik AI, Arezzo JC, et al. Diabetic neuropathies: a statement by the American Diabetes Association. Diab Care. 2005;28(4):956-962. doi:10.2337/diacare.28.4.956

2. Edwards JL, Vincent AM, Cheng HT, Feldman EL. Diabetic neuropathy: mechanisms to management. Pharmacol Ther. 2008;120 (1):1-34. doi:10.1016/j.pharmthera.2008.05.005

3. Calcutt NA. Potential mechanisms of neuropathic pain in diabetes. Int Rev Neurobiol. 2002;50:205-228.

4. Galer BS, Gianas A, Jensen MP. Painful diabetic polyneuropathy: epidemiology, pain description, and quality of life. Diabetes Res Clin Pract. 2000;47(2):123-128. doi:10.1016/S0168-8227(99)00112-6

5. Dworkin RH, Turk DC, Farrar JT, et al. Core outcome measures for chronic pain clinical trials: IMMPACT recommendations. Pain. 2005;113(1-2):9-19. doi:10.1016/j.pain.2004.09.012

6. Collins SL, Moore RA, McQuay H, Wiffen P. Antidepressants and anticonvulsants for diabetic neuropathy and postherpetic neuralgia: a quantitative systematic review. J Pain Symptom Manage. 2000;20 (6):449-458. doi:10.1016/S0885-3924(00)00218-9

7. Barrett AM, Lucero MA, Le T, Robinson RL, Dworkin RH, Chappell AS. Epidemiology, public health burden, and treatment of diabetic peripheral neuropathic pain: a review. Pain Med. 2007;8 (Suppl 2):S50-62. doi:10.1111/j.1526-4637.2006.00179.x

8. Nguyen DV, Shaw LC, Grant MB. Inflammation in the pathogenesis of microvascular complications in diabetes. Front Endocrinol. 2012;3:170. doi:10.3389/fendo.2012.00170

9. Cruz NG, Sousa LP, Sousa MO, Pietrani NT, Fernandes AP, Gomes KB. The linkage between inflammation and Type 2 diabetes mellitus. Diab Res Clin Pract. 2013;99(2):85-92. doi:10.1016/j. diabres.2012.09.003

10. Kanter JE, Bornfeldt KE. Inflammation and diabetes-accelerated atherosclerosis: myeloid cell mediators. Trends Endocrinol Metab. 2013;24(3):137-144. doi:10.1016/j.tem.2012.10.002

11. Kanter JE, Kramer F, Barnhart S, et al. Diabetes promotes an inflammatory macrophage phenotype and atherosclerosis through acyl-CoA synthetase 1. Proc Natl Acad Sci U S A. 2012;109(12):E715-724. doi:10.1073/pnas.1111600109

12. Rothwell NJ. Cytokines and acute neurodegeneration. Mol Psychiatry. 1997;2(2):120-121. doi:10.1038/sj.mp.4000223

13. Cheng HT, Dauch JR, Oh SS, Hayes JM, Hong Y, Feldman EL. p38 mediates mechanical allodynia in a mouse model of type 2 diabetes. Mol Pain. 2010;6:28. doi:10.1186/1744-8069-6-28

14. Cheng HT, Dauch JR, Hayes JM, Hong Y, Feldman EL. Nerve growth factor mediates mechanical allodynia in a mouse model of type 2 diabetes. J Neuropathol Exp Neurol. 2009;68(11):1229-1243. doi:10.1097/NEN.0b013e3181bef710 
15. Dauch JR, Bender DE, Luna-Wong LA, et al. Neurogenic factor-induced Langerhans cell activation in diabetic mice with mechanical allodynia. $J$ Neuroinflammation. 2013;10:64. doi:10.1186/1742-2094-10-64

16. Jancalek R, Dubovy P, Svizenska I, Klusakova I. Bilateral changes of TNF-alpha and IL-10 protein in the lumbar and cervical dorsal root ganglia following a unilateral chronic constriction injury of the sciatic nerve. J Neuroinflammation. 2010;7:11. doi:10.1186/1742-20947-11

17. Schafers M, Geis C, Svensson CI, Luo ZD, Sommer C. Selective increase of tumour necrosis factor-alpha in injured and spared myelinated primary afferents after chronic constrictive injury of rat sciatic nerve. Eur J Neurosci. 2003;17(4):791-804. doi:10.1046/j.14609568.2003.02504.x

18. Kleinschnitz C, Brinkhoff J, Sommer C, Stoll G. Contralateral cytokine gene induction after peripheral nerve lesions: dependence on the mode of injury and NMDA receptor signaling. Brain Res Mol Brain Res. 2005;136(1-2):23-28. doi:10.1016/j.molbrainres.2004.12.015

19. Vocanson M, Hennino A, Rozieres A, Poyet G, Nicolas JF. Effector and regulatory mechanisms in allergic contact dermatitis. Allergy. 2009;64(12):1699-1714. doi:10.1111/j.1398-9995.2009.02082.x

20. Clausen BE, Girard-Madoux MJ. IL-10 control of dendritic cells in the skin. Oncoimmunology. 2013;2(3):e23186. doi:10.4161/ onci. 23186

21. Mittal R, Gonzalez-Gomez I, Panigrahy A, Goth K, Bonnet R, Prasadarao NV. IL-10 administration reduces PGE-2 levels and promotes CR3-mediated clearance of Escherichia coli K1 by phagocytes in meningitis. J Exp Med. 2010;207(6):1307-1319. doi:10.1084/ jem. 20092265

22. Robertson SA, Skinner RJ, Care AS. Essential role for IL-10 in resistance to lipopolysaccharide-induced preterm labor in mice. J Immunol. 2006;177(7):4888-4896. doi:10.4049/ jimmunol.177.7.4888

23. Zhang C, Ward J, Dauch JR, Tanzi RE, Cheng HT. Cytokinemediated inflammation mediates painful neuropathy from metabolic syndrome. PLoS One. 2018;13(2):e0192333.

24. Dixon WJ. Efficient analysis of experimental observations. Annu Rev Pharmacol Toxicol. 1980;20:441-462. doi:10.1146/annurev. pa.20.040180.002301

25. Chaplan SR, Bach FW, Pogrel JW, Chung JM, Yaksh TL. Quantitative assessment of tactile allodynia in the rat paw J Neurosci Methods. 1994;53(1):55-63. doi:10.1016/0165-0270(94) 90144-9

26. Russell JW, Berent-Spillson A, Vincent AM, Freimann CL, Sullivan KA, Feldman EL. Oxidative injury and neuropathy in diabetes and impaired glucose tolerance. Neurobiol Dis. 2008;30 (3):420-429. doi:10.1016/j.nbd.2008.02.013

27. Ji RR, Samad TA, Jin SX, Schmoll R, Woolf CJ. p38 MAPK activation by NGF in primary sensory neurons after inflammation increases TRPV1 levels and maintains heat hyperalgesia. Neuron. 2002;36 (1):57-68. doi:10.1016/S0896-6273(02)00908-X

28. Kabashi E, Agar JN, Hong Y, et al. Proteasomes remain intact, but show early focal alteration in their composition in a mouse model of amyotrophic lateral sclerosis. J Neurochem. 2008;105(6):2353-2366. doi:10.1111/j.1471-4159.2008.05317.x

29. Cheng HT, Dauch JR, Hayes JM, Yanik BM, Feldman EL. Nerve growth factor/p38 signaling increases intraepidermal nerve fiber densities in painful neuropathy of type 2 diabetes. Neurobiol Dis. 2012;45(1):280-287. doi:10.1016/j.nbd.2011.08.011

30. Moore KW, de Waal Malefyt R, Coffman RL, O'Garra A. Interleukin-10 and the interleukin-10 receptor. Annu Rev Immunol. 2001;19:683-765. doi:10.1146/annurev.immunol.19.1.683

31. Shah N, Kammermeier J, Elawad M, Glocker EO. Interleukin-10 and interleukin-10-receptor defects in inflammatory bowel disease. Curr Allergy Asthma Rep. 2012;12(5):373-379. doi:10.1007/s11882-0120286-z
32. da Silva HDA, da Silva AP, da Silva HA, Asano NMJ, Maia Mde M, de Souza PRE. Interferon gamma and Interleukin 10 polymorphisms in Brazilian patients with systemic lupus erythematosus. Mol Biol Rep. 2014;41(4):2493-2500. doi:10.1007/s11033-014-3106-9

33. Acuner-Ozbabacan E, Engin B, Guven-Maiorov E, et al. The structural network of Interleukin-10 and its implications in inflammation and cancer. BMC Genomics. 2014;15(Suppl 4):S2. doi:10.1186/14712164-15-S4-S2

34. Bluher M, Fasshauer M, Tonjes A, Kratzsch J, Schon MR, Paschke R. Association of interleukin-6, C-reactive protein, interleukin-10 and adiponectin plasma concentrations with measures of obesity, insulin sensitivity and glucose metabolism. Exp Clin Endocrinol Diabetes. 2005;113(9):534-537. doi:10.1055/s-2005-872851

35. Esposito K, Pontillo A, Giugliano F, et al. Association of low interleukin-10 levels with the metabolic syndrome in obese women. $J$ Clin Endocrinol Metab. 2003;88(3):1055-1058.

36. van Exel E, Gussekloo J, de Craen AJ, et al. Low production capacity of interleukin-10 associates with the metabolic syndrome and type 2 diabetes: the Leiden 85-Plus Study. Diabetes. 2002;51(4):1088-1092. doi:10.2337/diabetes.51.4.1088

37. Krukowski K, Eijkelkamp N, Laumet G, et al. CD8+ T cells and endogenous IL-10 are required for resolution of chemotherapy-induced neuropathic pain. $J$ Neurosci. 2016;36 (43):11074-11083. doi:10.1523/JNEUROSCI.3708-15.2016

38. Ruohonen S, Jagodi M, Khademi M, et al. Contralateral non-operated nerve to transected rat sciatic nerve shows increased expression of IL-1beta, TGF-beta1, TNF-alpha, and IL-10. J Neuroimmunol. 2002;132(1-2):11-17. doi:10.1016/S0165-5728(02)00281-3

39. Jancalek R, Svizenska I, Klusakova I, Dubovy P. Bilateral changes of IL-10 protein in lumbar and cervical dorsal root ganglia following proximal and distal chronic constriction injury of peripheral nerve. Neurosci Lett. 2011;501(2):86-91. doi:10.1016/j. neulet.2011.06.052

40. Bethea JR, Nagashima H, Acosta MC, et al. Systemically administered interleukin-10 reduces tumor necrosis factor-alpha production and significantly improves functional recovery following traumatic spinal cord injury in rats. J Neurotrauma. 1999;16(10):851-863. doi:10.1089/neu.1999.16.851

41. Brewer KL, Bethea JR, Yezierski RP. Neuroprotective effects of interleukin-10 following excitotoxic spinal cord injury. Exp Neurol. 1999;159(2):484-493. doi:10.1006/exnr.1999.7173

42. Grilli M, Barbieri I, Basudev H, et al. Interleukin-10 modulates neuronal threshold of vulnerability to ischaemic damage. Eur $J \quad$ Neurosci. 2000;12(7):2265-2272. doi:10.1046/j.14609568.2000.00090.x

43. Bachis A, Colangelo AM, Vicini S, et al. Interleukin-10 prevents glutamate-mediated cerebellar granule cell death by blocking caspase-3-like activity. $J$ Neurosci. 2001;21(9):3104-3112. doi:10.1523/JNEUROSCI.21-09-03104.2001

44. Kanaan SA, Poole S, Saade NE, Jabbur S, Safieh-Garabedian B. Interleukin-10 reduces the endotoxin-induced hyperalgesia in mice. J Neuroimmunol. 1998;86(2):142-150. doi:10.1016/S0165-5728(98) 00027-7

45. Wagner R, Janjigian M, Myers RR. Anti-inflammatory interleukin-10 therapy in CCI neuropathy decreases thermal hyperalgesia, macrophage recruitment, and endoneurial TNF-alpha expression. Pain. 1998;74(1):35-42. doi:10.1016/S0304-3959(97)00148-6

46. Plunkett JA, Yu CG, Easton JM, Bethea JR, Yezierski RP. Effects of interleukin-10 (IL-10) on pain behavior and gene expression following excitotoxic spinal cord injury in the rat. Exp Neurol. 2001;168 (1):144-154. doi:10.1006/exnr.2000.7604

47. Dengler EC, Alberti LA, Bowman BN, et al. Improvement of spinal non-viral IL-10 gene delivery by D-mannose as a transgene adjuvant to control chronic neuropathic pain. $J$ Neuroinflammation. 2014;11:92. doi:10.1186/1742-2094-11-92 
48. Zhou Z, Peng X, Hao S, Fink DJ, Mata M. HSV-mediated transfer of interleukin-10 reduces inflammatory pain through modulation of membrane tumor necrosis factor alpha in spinal cord microglia. Gene Ther. 2008;15(3):183-190. doi:10.1038/sj.gt.3303054

49. Shen KF, Zhu HQ, Wei XH, et al. Interleukin-10 down-regulates voltage gated sodium channels in rat dorsal root ganglion neurons. Exp Neurol. 2013;247:466-475. doi:10.1016/j.expneurol.2013.01.018

50. Zhou Z, Peng X, Insolera R, Fink DJ, Mata M. IL-10 promotes neuronal survival following spinal cord injury. Exp Neurol. 2009;220(1):183-190.

51. Iwasa T, Afroz S, Inoue M, et al. IL-10 and CXCL2 in trigeminal ganglia in neuropathic pain. Neurosci Lett. 2019;703:132-138. doi:10.1016/j.neulet.2019.03.031

52. Wang X, Coradin T, Helary C. Modulating inflammation in a cutaneous chronic wound model by IL-10 released from collagen-silica nanocomposites via ene delivery. Biomater Sci. 2018;6 (2):398-406. doi:10.1039/C7BM01024A

53. Beissert S, Ullrich SE, Hosoi J, Granstein RD. Supernatants from UVB radiation-exposed keratinocytes inhibit Langerhans cell presentation of tumor-associated antigens via IL-10 content. J Leukoc Biol. 1995;58(2):234-240. doi:10.1002/jlb.58.2.234
54. Chatelain R, Wollenberg A, Martin C, et al. IL-10 inhibits ICAM-1 expression on human Langerhans cells but not on keratinocytes, dermal endothelial cells or fibroblasts. Arch Dermatol Res. 1998;290(9):477-482. doi:10.1007/s004030050339

55. Qureshi AA, Hosoi J, Xu S, Takashima A, Granstein RD, Lerner EA. Langerhans cells express inducible nitric oxide synthase and produce nitric oxide. J Invest Dermatol. 1996;107(6):815-821. doi:10.1111/ 1523-1747.ep12330572

56. Bruch-Gerharz D, Ruzicka T, Kolb-Bachofen V. Nitric oxide in human skin: current status and future prospects. J Invest Dermatol. 1998;110(1):1-7. doi:10.1046/j.1523-1747.1998.00084.x

57. Mowbray M, Tan X, Wheatley PS, Rossi AG, Morris RE, Weller RB. Topically applied nitric oxide induces T-lymphocyte infiltration in human skin, but minimal inflammation. J Invest Dermatol. 2008;128 (2):352-360. doi:10.1038/sj.jid.5701096

58. Cruz MT, Neves BM, Goncalo M, Figueiredo A, Duarte CB, Lopes MC. Effect of skin sensitizers on inducible nitric oxide synthase expression and nitric oxide production in skin dendritic cells: role of different immunosuppressive drugs. Immunopharmacol Immunotoxicol. 2007;29 (2):225-241. doi:10.1080/08923970701512304

\section{Publish your work in this journal}

The Journal of Pain Research is an international, peer reviewed, open access, online journal that welcomes laboratory and clinical findings in the fields of pain research and the prevention and management of pain. Original research, reviews, symposium reports, hypothesis formation and commentaries are all considered for publication. The manuscript management system is completely online and includes a very quick and fair peer-review system, which is all easy to use. Visit http:// www.dovepress.com/testimonials.php to read real quotes from published authors. 